\title{
Respon Pertumbuhan dan Hasil Tanaman Kacang Tanah Pada Aplikasi Biochar Bambu
}

\author{
Kadek Suparta, Luh Kartini, Yohanes Parlindungan Situmeang \\ Fakultas Pertanian Universitas Warmadewa \\ E-mail: luhkartini59@yahoo.com; ypsitumeang63@gmail.com
}

\begin{abstract}
This study aims to determine the effect of bamboo biochar dose on the growth and yield of peanut crops. This study used a randomized block design with one factor. The tested treatments were dosage of biochar fertilizer with 4 dosage levels and one treatment without biochar dose (control), with the treatment arrangement as follows: without biochar, 4 ton ha ${ }^{-1}, 8$ ton ha-, 12 ton ha $a^{-1}, 16$ ton ha ${ }^{-1}$. This treatment was repeated 3 times to obtain 15 plot experiments. The results showed that the biochar dose treatment had significant effect on all observed variables, except the variable of plant height and maximum number of leaves per plant had no significant effect. The highest yield of dry seed oven of seeds per plant was obtained in the dosage of 4 ton ha $a^{-1}$ biochar dose of 21.83 $\mathrm{g}$, an increase of $111.81 \%$ compared with no biochar $10.33 \mathrm{~g}$. Based on regression analysis, the optimum dosage of biochar is 7.50 ton ha ${ }^{-1}$, with dry weight of oven seed per plant maximum $19.03 \mathrm{~g}$.
\end{abstract}

\section{Keywords: Bamboo biochar, peanut yield}

\section{Pendahuluan}

Kacang tanah (Arachis hypogaea L.) merupakan komoditas terpenting setelah kedelai yang memiliki peran strategis pangan nasional sebagai sumber protein dan minyak nabati. Kacang tanah dimanfaatkan sebagai bahan pangan konsumsi langsung dan bahan makanan, sehingga kebutuhan kacang tanah terus meningkat setiap tahunnya sejalan dengan peningkatan jumlah penduduk (Balitkabi, 2008). Kacang tanah sebagai bahan makanan yang paling banyak digunakan oleh bahan baku industri yang diubah dengan bentuk lain seperti kacang atom, rempeyek, manisan dan lain-lain (Pitojo, 2010). Selain itu, sisa hasil kacang tanah yang tidak dipakai dapat digunakan sebagai makanan ternak sehingga seluruh bagian dari kacang tanah dapat digunakan sebagai bahan baku makanan industri maupun pakan ternak.

Pertanian tanaman pangan terutama tanaman kacang tanah di lahan kering dihadapkan kepada masalah pengelolaan lahan yang tidak sesuai dengan potensi dan kesesuaiannya. Selain untuk menanggulangi penurunan kesuburan tanah, kegiatan rehabilitasi lahan juga harus diarahkan pada perbaikan sifat fisik tanah. Peningkatan produksi kacang tanah menghadapi berbagai kendala, seperti alih fungsi lahan, hama dan penyakit tanaman, serta kendala penggunaan pupuk organik dan pupuk hayati yang masih rendah dikalangan petani (Dirjen Tanaman Pangan, 2012).

Pemulihan atau rehabilitasi sifat fisik tanah perlu dilakukan dengan menggunakan berbagai bahan amelioran yang mudah tersedia. Salah satu upaya perbaikan kualitas tanah yang dapat ditempuh adalah penggunaan bahan-bahan yang tergolong sebagai bahan pembenah tanah. Dalam upaya meningkatkan kualitas sifat fisik tanah, sebaiknya dipilih bahan pembenah dari bahan yang sulit terdekomposisi agar dapat bertahan lama dalam tanah. Bahan yang mudah diperoleh dan relatif murah adalah limbah bambu yang sulit terdekomposisi. Bahan baku limbah bambu diproses secara pirolisis melalui pembakaran tidak sempurna (non aerob) sehingga diperoleh arang yang mengandung karbon aktif yang dikenal dengan biochar yang selanjutnya diaplikasikan ke dalam tanah untuk memperbaiki kualitas tanah (Nurida dan Rachman, 2012). 
Bahan baku limbah bambu di Bali khususnya kabupaten Bangli cukup tersedia (Situmeang, dkk., 2013). Hasil penelitian pot di rumah kaca menunjukkan bahwa pemanfaatan biochar limbah bambu dosis 10 ton ha-1 memberikan pengaruh nyata terhadap tinggi tanaman dan berat basah total tanaman jagung (Situmeang dan Sudewa, 2013, Situmeang dkk. 2015). Pemberian biochar 15 ton ha-1 dapat menaikkan berat segar 100 biji per tanaman jagung dari 18,67 g (kontrol) menjadi 26,78 g atau meningkat sebesar 43,44\% (Artawan dkk., 2015). Pengaruh biochar terhadap produktivitas tanaman sangat bergantung pada dosis yang digunakan. Hasil penelitian (Gani, 2009).menunjukkan bahwa pemberian biochar 4-8 ton ha1 dapat meningkatkan produktivitas tanaman sebesar $20-220 \%$, tergantung pada komoditas yang dibudidayakan

Penggunaan bahan pembenah tanah berbahan baku limbah pertanian yang sulit terdekomposisi merupakan salah satu alternatif yang dapat ditempuh untuk mempercepat peningkatan kualitas sifat fisik tanah. Kendala-kendala fisik dalam pemanfaatan lahan kering sebagai sumber pangan dapat dikurangi sehingga produksi tanaman dapat ditingkatkan. Luasnya kisaran sifat biochar sesuai dengan bahan dasarnya, dan interaksi yang beragam antara biochar dengan tipe tanah, maka dilakukan penelitian untuk peningkatan produktivitas tanaman serta pengembangan pemanfaatan biochar secara luas. Salah satunya dengan menggunakan biochar bambu yang diperoleh dari pembakaran anaerob limbah bambu.

\section{Bahan dan Metoda}

\subsection{Tempat dan waktu percobaan}

Percobaan ini merupakan percobaan lapangan yang dilaksanakan di kebun UPTD Perbenihan Palawija dan Hortikultura, di Desa Singarata, Kecamatan Rendang, Kabupaten Karangasem, dengan ketinggian tempat +586 meter di atas permukaan laut. Percobaan ini berlangsung dari bulan Maret hingga Juni 2014. Hasil analisis tanah tempat percobaan dapat dilihat pada Tabel 1

Tabel 1

Hasil analisis tanah tempat percobaan

\begin{tabular}{llll}
\hline No. & Jenis analisis & Nilai & Keterangan \\
\hline 1 & Tekstur : & & \\
& - Pasir (\%) & 63,67 & Lempung berpasir \\
& - Debu (\%) & 26,47 & \\
& - Liat (\%) & 9,86 & \\
2 & Kadar air : & 5,32 & \\
& - Kering udara (\%) & \\
& - Kapasitas lapang (\%) & 37,24 & Netral \\
3 & pH tanah & 6,9 & Sangat rendah \\
4 & Kadar garam total (mm hos/cm) & 0,42 & Sedang \\
5 & C- organik (\%) & 2,87 & Rendah \\
6 & N-total (\%) & 0,17 & Sedang \\
7 & P-tersedia (ppm) & 16,68 & Sedang \\
8 & K-tersedia (ppm) & 167,48 & \\
\hline Sumber: & Laboratorium Tanah Fakultas Pertanian Universitas Udayana Denpasar, 2013 \\
1
\end{tabular}


Tabel 2

Hasil analisis pembenah tanah biochar bambu

\begin{tabular}{llll}
\hline No. & Jenis analisis & Nilai & Keterangan \\
\hline 1 & Kadar air kering udara (\%) & 30,29 & \\
2 & pH biochar & 8,20 & Agak alkalis \\
3 & Kadar garam total $(\mathrm{mm}$ hos $/ \mathrm{cm})$ & 0,39 & Sangat rendah \\
4 & $\mathrm{C}-$ organik $(\%)$ & 12,69 & Sangat tinggi \\
5 & $\mathrm{~N}-$ total $(\%)$ & 0,10 & Rendah \\
6 & $\mathrm{C} / \mathrm{N}$ & 126,90 & Sangat tinggi \\
6 & $\mathrm{P}-$ tersedia $(\mathrm{ppm})$ & 787,55 & Sangat tinggi \\
7 & $\mathrm{KTK}(\mathrm{me} / 100 \mathrm{~g})$ & 13,81 & Rendah \\
8 & $\mathrm{~KB}(\%)$ & 422,63 & Sangat tinggi \\
\hline \multicolumn{2}{l}{ Sumber: } & Laboratorium Tanah Fakultas Pertanian Universitas Udayana Denpasar, 2014
\end{tabular}

\section{Bahan dan Alat Percobaan}

Bahan-bahan yang digunakan dalam penelitian ini adalah kacang tanah dan biochar. Sedangkan alatalat digunakan antara lain: cangkul, garu, pisau, meteran, ember, sprayer, alat tulis, bambu, timbangan, dan oven. Hasil analisis biochar bambu dapat dilihat pada Tabel 2.

\subsection{Rancangan Percobaan}

Percobaan ini merupakan percobaan satu faktor dengan rancangan acak kelompok (RAK) sederhana. Perlakuan yang diuji dosis pupuk biochar dengan 4 tingkat dosis dan satu perlakuan tanpa dosis biochar (kontrol), dengan susunan perlakuan sebagai berikut: B0 $=0$ ton $\mathrm{ha}^{-1}$ (tanpa biochar), B1= ton ha ${ }^{-1}$ (400 $\mathrm{g} /$ petak), B2 = ton ha ${ }^{-1}(800 \mathrm{~g} /$ petak $), \mathrm{B} 3=12$ ton ha ${ }^{-1}(1.200 \mathrm{~g} /$ petak $), \mathrm{B} 4=16$ ton ha ${ }^{-1}(1.600 \mathrm{~g} /$ petak $)$. Dengan demikian terdapat 5 perlakuan, masing-masing perlakuan diulang 3 kali sehingga terdapat 15 petak percobaan.

\section{Hasil dan Pembahasan}

Berdasarkan hasil yang diperoleh dalam penelitian ini dan setelah dilakukan analisis statistik, didapat signifikansi pengaruh perlakuan dosis biochar terhadap variabel pertumbuhan dan hasil yang diamati disajikan pada Tabel 3. Dari Tabel 3 dapat diketahui bahwa perlakuan dosis biochar menunjukkan pengaruh nyata $(\mathrm{P}<0,05)$ sampai sangat nyata $(\mathrm{P}<0,01)$ terhadap seluruh variabel yang diamati, kecuali variabel tinggi tanaman dan jumlah daun maksimum per tanaman berpengaruh tidak nyata $(\mathrm{P}>0,05)$.

Tabel 3

Signifikansi pengaruh perlakuan dosis biochar terhadap variabel yang diamati

\begin{tabular}{|c|c|}
\hline Variabel & Perlakuan Biochar \\
\hline 1. Tinggi tanaman maksimum per tanaman $(\mathrm{cm})$ & ns \\
\hline 2. Jumlah daun maksimum per tanaman (helai) & ns \\
\hline 3. Berat segar biji per tanaman $(\mathrm{g})$ & $* *$ \\
\hline 4. Berat segar polong per tanaman $(\mathrm{g})$ & * \\
\hline 5. Berat segar berangkasan per tanaman $(\mathrm{g})$ & $* *$ \\
\hline 6. Berat kering oven biji per tanaman $(\mathrm{g})$ & $* *$ \\
\hline 7. Berat kering oven berangkasan per tanaman (g) & $* *$ \\
\hline 8. Berat kering oven polong per tanaman $(\mathrm{g})$ & $* *$ \\
\hline 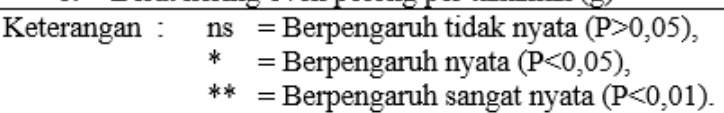 & \\
\hline
\end{tabular}


Berdasarkan Tabel 4 menunjukkan bahwa perlakuan biochar bambu 4 ton ha $^{-1}$ cenderung memberikan hasil maksimum tinggi tanaman dan jumlah daun, masing-masing dengan nilai $39,00 \mathrm{~cm}$ dan 48,67 helai. Pemberian biochar bambu ton $\mathrm{ha}^{-1}$ juga cenderung memberikan hasil tertinggi pada variabel berat segar biji, berat segar polong, dan berat segar brangkasan masing-masing dengan nilai $49,33 \mathrm{~g}, 59,90 \mathrm{~g}$, dan $88,67 \mathrm{~g}$ (Tabel 5)

Tabel 4

Rata-rata tinggi tanaman karena pengaruh dosis biochar bambu

\begin{tabular}{ccc}
\hline $\begin{array}{c}\text { Perlakuan } \\
\text { Biochar Bambu }\end{array}$ & $\begin{array}{c}\text { Tinggi Tanaman } \\
(\mathrm{cm})\end{array}$ & $\begin{array}{c}\text { Jumlah Daun } \\
(\text { helai })\end{array}$ \\
\hline 0 ton ha-1 $(\mathrm{B} 0)$ & $38,07 \mathrm{a}$ & $48,00 \mathrm{a}$ \\
4 ton $^{-1}(\mathrm{~B} 1)$ & $39,00 \mathrm{a}$ & $48,67 \mathrm{a}$ \\
8 ton $\mathrm{ha}^{-1}(\mathrm{~B} 2)$ & $38,47 \mathrm{a}$ & $48,33 \mathrm{a}$ \\
12 ton ha ${ }^{-1}(\mathrm{~B} 3)$ & $38,37 \mathrm{a}$ & $48,00 \mathrm{a}$ \\
16 ton ha ${ }^{-1}(\mathrm{~B} 4)$ & $37,83 \mathrm{a}$ & $47,67 \mathrm{a}$ \\
\hline Keterangan : Huruf yang sama dibelakang nilai rata-rata, berbeda tidak nyata pada uji Duncan $5 \%$
\end{tabular}

Tabel 5

Rata-rata berat segar biji, berat segar polong, dan berat segar brangkasan karena pengaruh dosis biochar bambu

\begin{tabular}{|c|c|c|c|}
\hline $\begin{array}{c}\text { Perlakuan } \\
\text { Biochar Bambu }\end{array}$ & $\begin{array}{l}\text { Berat Segar Biji } \\
(\mathrm{g})\end{array}$ & $\begin{array}{l}\text { Berat Segar Polong } \\
\text { (g) }\end{array}$ & $\begin{array}{c}\text { Berat Segar Berangkasan } \\
\text { (g) }\end{array}$ \\
\hline 0 ton $\mathrm{ha}^{-1}(\mathrm{~B} 0)$ & $20,00 \mathrm{~d}$ & $39,29 \mathrm{c}$ & $62,33 \mathrm{~d}$ \\
\hline 4 ton $\mathrm{ha}^{-1}(\mathrm{~B} 1)$ & $49,33 \mathrm{a}$ & $59,90 \mathrm{a}$ & $88,67 \mathrm{a}$ \\
\hline 8 ton $\mathrm{ha}^{-1}(\mathrm{~B} 2)$ & $41,67 \mathrm{~b}$ & $50,60 \mathrm{ab}$ & $86,00 \mathrm{a}$ \\
\hline 12 ton ha-1 $(\mathrm{B} 3)$ & $35,00 \mathrm{~b}$ & $50,44 \mathrm{abc}$ & $76,33 \mathrm{bc}$ \\
\hline 16 ton $\mathrm{ha}^{-1}(\mathrm{~B} 4)$ & $26,67 \mathrm{~cd}$ & $48,31 \mathrm{bc}$ & $73,33 \mathrm{c}$ \\
\hline
\end{tabular}

Keterangan : Huruf yang sama dibelakang nilai rata-rata, berbeda tidak nyata pada uji Duncan $5 \%$

Tabel 6

Rata-rata berat kering oven biji, berat kering oven brangkasan, dan berat kering oven polong karena pengaruh dosis biochar bambu

\begin{tabular}{|c|c|c|c|}
\hline $\begin{array}{c}\text { Perlakuan } \\
\text { Biochar Bambu }\end{array}$ & $\begin{array}{c}\text { Berat Kering } \\
\text { Oven Biji } \\
\text { (g) }\end{array}$ & $\begin{array}{c}\text { Berat Kering Oven } \\
\text { Berangkasan } \\
(\mathrm{g})\end{array}$ & $\begin{array}{l}\text { Berat Kering Oven } \\
\text { Polong } \\
(\mathrm{g})\end{array}$ \\
\hline 0 ton $\mathrm{ha}^{-1}(\mathrm{~B} 0)$ & $10,33 \mathrm{~d}$ & $30,00 \mathrm{~d}$ & $25,58 \mathrm{~d}$ \\
\hline 4 ton $\mathrm{ha}^{-1}(\mathrm{~B} 1)$ & $21,83 \mathrm{a}$ & $46,83 \mathrm{a}$ & $42,90 \mathrm{a}$ \\
\hline 8 ton $\mathrm{ha}^{-1}(\mathrm{~B} 2)$ & $18,00 \mathrm{~b}$ & $43,00 \mathrm{~b}$ & $36,83 \mathrm{~b}$ \\
\hline 12 ton $\mathrm{ha}^{-1}(\mathrm{~B} 3)$ & $13,67 \mathrm{c}$ & $33,67 \mathrm{c}$ & $34,85 \mathrm{bc}$ \\
\hline 16 ton ha ${ }^{-1}(\mathrm{~B} 4)$ & $12,00 \mathrm{~cd}$ & $31,00 \mathrm{~d}$ & $30,98 \mathrm{bcd}$ \\
\hline
\end{tabular}

Hasil berat kering oven biji per tanaman terberat diperoleh pada perlakuan biochar dosis 4 ton ha ${ }^{-1}$ (B1) yaitu 21,83 g mengalami peningkatan $111,81 \%$ bila dibandingkan dengan tanpa biochar (B0) yaitu 10,33 g (Tabel 6). Hasil berat kering oven biji per tanaman ini juga didukung variabel berat kering oven berangkasan per tanaman. Hasil berat kering oven berangkasan tertinggi diperoleh pada perlakuan biochar dosis ton $\mathrm{ha}^{-1}$ (B1) yaitu 46,83 g yang mengalami peningkatan 56,10\% bila dibandingkan dengan tanpa biochar (B0) yaitu 30,00 g (Tabel 6).

Tingginya berat kering oven biji pada dosis biochar 4 ton ha $^{-1}$ didukung oleh variabel tinggi tanaman maksimum $(\mathrm{r}=0,92 * *)$, jumlah daun maksimum $(\mathrm{r}=0,90 * *)$, berat segar biji per tanaman $(\mathrm{r}=0,98 * *)$, berat segar polong per tanaman $\left(\mathrm{r}=0,90^{* *}\right)$, berat segar berangkasan per tanaman $(\mathrm{r}=0,94 * *)$, dan berat kering oven polong per tanaman $\left(\mathrm{r}=0,96^{* *}\right)$. Hal ini diduga disebabkan biochar sebagai 
pembenah tanah mampu memperbaiki sifat fisik tanah seperti struktur, konsistensi, porositas, lengas, dan daya mengikat air, yang dapat mendorong peningkatan aktivitas mikroba di dalam tanah dan menjamin pertumbuhan akar tanaman di dalam tanah. Biochar dapat berfungsi sebagai salah satu bahan pembentuk agregat tanah, yang mempunyai peran sebagai bahan perekat antar partikel tanah untuk bersatu menjadi agregat tanah, sehingga biochar penting dalam pembentukan struktur tanah. Pengaruh pemberian biochar terhadap struktur tanah sangat berkaitan dengan tekstur tanah. Pada tanah lempung yang berat, terjadi perubahan struktur gumpal kasar dan kuat menjadi struktur yang lebih halus tidak kasar, dengan derajat struktur sedang hingga kuat, sehingga lebih mudah untuk diolah. Kondisi perbaikan sifat fisik tanah ini juga didukung sifat kimia biochar bambu (Tabel 2) seperti; pH biochar agak alkalis yang dapat menurunkan $\mathrm{pH}$ tanah, C-organik biochar sangat tinggi yang dapat meningkatkan kandungan bahan organik tanah, $\mathrm{C} / \mathrm{N}$ sangat tinggi yang dapat menyebabkan dekomposisi berlangsung lambat dan biochar dapat bertahan lebih lama di dalam tanah, P-tersedia sangat tinggi sebagai sumber hara $\mathrm{P}$ yang dapat mendorong pertumbuhan dan hasil tanaman kacang tanah.

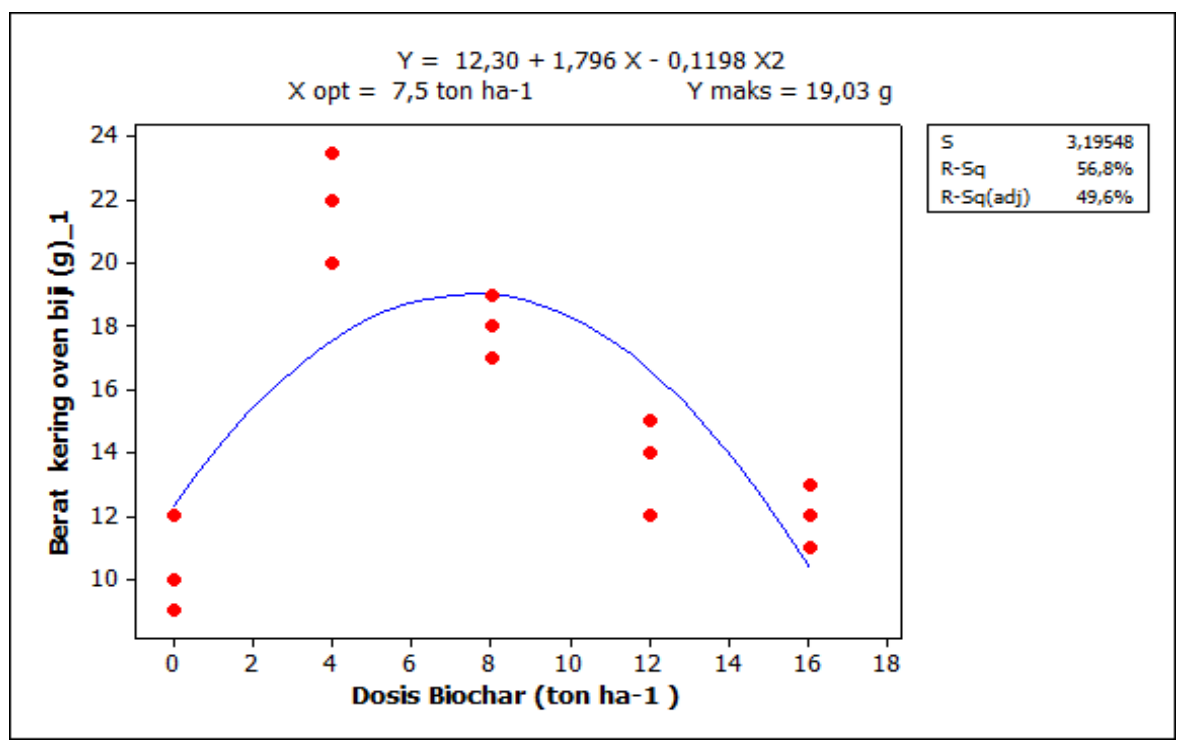

Gambar 1

Hubungan dosis biochar dengan berat kering oven biji per tanaman

Hasil analisis regresi dosis biochar dengan berat kering oven biji per tanaman menunjukkan hubungan kuadratik dengan persamaan garis regresi : $\hat{Y}=12,30+1,796 \mathrm{X}-0,1198 \mathrm{X}^{2}$ dengan koefisien determinasi $\left(\mathrm{R}^{2}\right)$ sebesar 56,80\% (Gambar 1). Dari hasil analisis regresi didapatkan dosis optimum biochar yaitu 7,50 ton $\mathrm{ha}^{-1}$, dengan berat kering oven biji per tanaman maksimum 19,03 g. Berdasarkan hasil analisis regresi menunjukkan bahwa berat kering oven biji per tanaman makin tinggi dengan makin meningkatnya dosis biochar sampai optimum, kemudian mengalami penurunan bila melebihi dosis optimum. Sejalan dengan hasil penelitian Nurida dan Rahman (2012) bahwa pemberian formula pembenah tanah biochar dengan dosis 5,0-7,5 ton $\mathrm{ha}^{-1}$ mampu memperbaiki sifat fisik dan kimia tanah: (1) persentase pori air tersedia menjadi 9,18-10.11\% vol dari semula 6,69\% vol (tanpa pembenah tanah). (2) Kandungan P-tersedia meningkat menjadi 29,12-30,71 ppm dari 24,52 ppm (tanpa pembenah tanah), (3) K total meningkat menjadi 5,13-6,43 ppm dari 3,08 ppm (tanpa pembenah tanah), KTK tanah meningkat menjadi 5,91-6,00 $\mathrm{cmol}^{(+)} \mathrm{kg}-1$ dari $4,71 \mathrm{cmol}^{(+)} \mathrm{kg}^{-1}$, (4) respirasi mikroorganisme meningkat menjadi 9,88-10,78 $\mathrm{mgCO}_{2} \mathrm{~kg}^{-1}$ tanah hari ${ }^{-1}$ dari semula $8,71 \mathrm{mgCO}_{2} \mathrm{~kg}^{-1}$ tanah hari ${ }^{-1}$ (tanpa pembenah tanah). 


\section{Kesimpulan}

Perlakuan dosis biochar menunjukkan pengaruh nyata sampai sangat nyata terhadap seluruh variabel yang diamati, kecuali variabel tinggi tanaman dan jumlah daun maksimum per tanaman berpengaruh tidak nyata. Hasil berat kering oven biji per tanaman terberat diperoleh pada pemberian biochar dosis 4 ton ha $^{-1}$ yaitu $21,83 \mathrm{~g}$ mengalami peningkatan $111,81 \%$ dibandingkan tanpa biochar 10,33 g. Dari hasil analisis regresi didapatkan dosis optimum biochar yaitu 7,50 ton $\mathrm{ha}^{-1}$, dengan berat kering oven biji per tanaman maksimum 19,03 g.

\section{Referensi}

Artawan, I.K., Situmeang, Y.P., \& Wahyuni, M.D. (2015). The Effect of How The Bamboo Biochar Placement and Dose Towards The Growth and Production of Sweet Corn. Wicaksana, 24(1), 18-28.

Balai Penelitian Tanaman Kacang-kacangan dan Umbi-umbian (Balitkabi), (2008). Teknologi Produksi Kacang Tanah. Balai Penelitian Tanaman Kacang-kacangan dan Umbi-umbian. Malang.

Direktorat Jendral Tanaman Pangan (2012). Pengelolaan Produksi Tanaman Aneka dan Umbi. Jakarta.

Gani, A. (2009). Biochar penyelamat lingkungan. Warta Penelitian dan Pengembangan Pertanian, Vol. 31 No:6

Nurida, N.L \& Rachman, A. (2012). Alternatif Pemulihan Lahan Kering Masam Terdegradasi dengan Formula Pembenah Tanah Biochar di Typic Kanhapludults Lampung.Badan Litbang Pertanian, Balai Penelitian Tanah.

Pitojo (2010). Benih Kacang Tanah. Yogyakarta: Kanisius.

Situmeang, Y.P, Udayana, I.G.B., Mayun Wirajaya, A.A.N., Suarta, M., Suaria I.N, Sadguna, D.N., Yuliartini, M.S., \& Wahyuni, N.M.D. (2013). The Potential of Bamboo \& Bamboo-waste as Source of Supply Feedstock Community Based Biomass Fuel Cell at Bangli Regency-Bali Province.

Situmeang, Y.P., \& Sudewa, K.A. (2013). Respon Pertumbuhan Vegetatif Tanaman Jagung Pulut pada Aplikasi Biochar Limbah Bambu.

Situmeang, Y. P., Adnyana, I. M., Subadiyasa, I. N. N., \& Merit, I. N. (2015). Effect of Dose Biochar Bamboo, Compost, and Phonska on Growth of Maize (Zea mays L.) in Dryland. International Journal on Advanced Science, Engineering and Information Technology, 5(6), 433-439. 